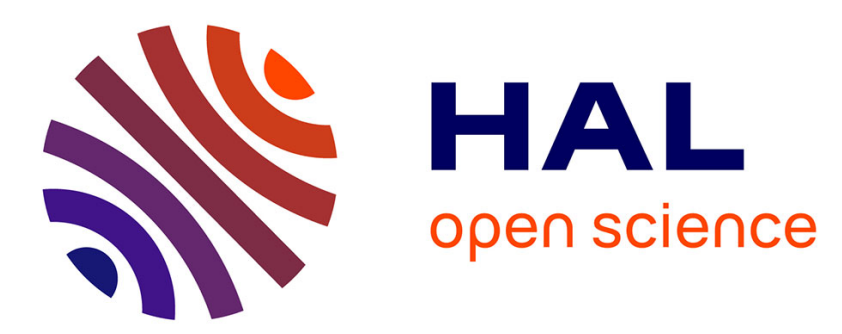

\title{
Evaluation of the effects of the R- and S- enantiomers of salbutamol on equine isolated bronchi
}

Maria G. Matera, Luigino Calzetta, Paola Rogliani, Floriana Bardaro, Clive P. Page, Mario Cazzola

\section{- To cite this version:}

Maria G. Matera, Luigino Calzetta, Paola Rogliani, Floriana Bardaro, Clive P. Page, et al.. Evaluation of the effects of the R- and S- enantiomers of salbutamol on equine isolated bronchi. Pulmonary Pharmacology \& Therapeutics, 2011, 24 (2), pp.221. 10.1016/j.pupt.2010.12.008 . hal-00724890

\section{HAL Id: hal-00724890 \\ https://hal.science/hal-00724890}

Submitted on 23 Aug 2012

HAL is a multi-disciplinary open access archive for the deposit and dissemination of scientific research documents, whether they are published or not. The documents may come from teaching and research institutions in France or abroad, or from public or private research centers.
L'archive ouverte pluridisciplinaire HAL, est destinée au dépôt et à la diffusion de documents scientifiques de niveau recherche, publiés ou non, émanant des établissements d'enseignement et de recherche français ou étrangers, des laboratoires publics ou privés. 


\section{Accepted Manuscript}

Title: Evaluation of the effects of the R- and S- enantiomers of salbutamol on equine isolated bronchi

Authors: Maria G. Matera, Luigino Calzetta, Paola Rogliani, Floriana Bardaro, Clive P. Page, Mario Cazzola

PII:

$$
\text { S1094-5539(10)00160-4 }
$$

DOI:

$$
\text { 10.1016/j.pupt.2010.12.008 }
$$

Reference: $\quad$ YPUPT 1066

To appear in: Pulmonary Pharmacology \& Therapeutics

Received Date: 13 July 2010

Revised Date: 1 December 2010

Accepted Date: 23 December 2010

Please cite this article as: Matera MG, Calzetta L, Rogliani P, Bardaro F, Page CP, Cazzola M. Evaluation of the effects of the R- and S- enantiomers of salbutamol on equine isolated bronchi, Pulmonary Pharmacology \& Therapeutics (2010), doi: 10.1016/j.pupt.2010.12.008

This is a PDF file of an unedited manuscript that has been accepted for publication. As a service to our customers we are providing this early version of the manuscript. The manuscript will undergo copyediting, typesetting, and review of the resulting proof before it is published in its final form. Please note that during the production process errors may be discovered which could affect the content, and all legal disclaimers that apply to the journal pertain. 


\title{
Evaluation of the effects of the R- and S- enantiomers of salbutamol on equine isolated bronchi
}

\author{
Maria G. Matera ${ }^{1}$, Luigino Calzetta ${ }^{2,3}$, Paola Rogliani ${ }^{3}$, Floriana Bardaro ${ }^{3}$, Clive P. Page ${ }^{2}$, \\ Mario Cazzola ${ }^{3 *}$
}

${ }^{1}$ Department of Experimental Medicine, Second University of Naples, Naples, Italy

${ }^{2}$ The Sackler Institute of Pulmonary Pharmacology, Institute of Pharmaceutical Sciences, King's College London, London, UK

${ }^{3}$ Department of Internal Medicine, University of Rome 'Tor Vergata', Rome, Italy

*Corresponding author: Università di Roma 'Tor Vergata', Dipartimento di Medicina Interna, Via Montpellier 1, 00133 Roma, Italy, E-mail address: mario.cazzola@uniroma2.it (M. Cazzola) 


\section{Abstract:}

Background: Equine obstructive pulmonary disease, also known as heaves or recurrent airway obstruction (RAO) is a common equine pulmonary disease with some similarities to human asthma and COPD, which represents a major cause of morbidity and loss of lung performance. Salbutamol has been widely used for the treatment of human airway diseases and has usually been prepared as the racemic form of the drug. However, recently the $\mathrm{R}$ - enantiomer of salbutamol has been introduced into clinical practice in the treatment of asthma in humans and this has been suggested to be an improvement on the racemic form of the drug; therefore thus the S-enantiomer has been demonstrated to have adverse effects in the lung and thus using the R-enantiomer may improve the therapeutic ratio. However, little is known about the properties of the R- and S-enantiomers of salbutamol in equine airways and the present study has evaluated the relaxant effects of racemic $\beta_{2}$ agonists in comparison with the $R$ - and $S$ - enantiomers in isolated equine isolated bronchi, as well as the bronchoprotective effects of these drugs on cholinergic and histaminergic pathway.

Methods: We have studied the effects of the R- and S- enantiomers of salbutamol on bronchi isolated from RAO-affected or unaffected horses. The first study assayed the relaxant effects of $\mathrm{R}$ - and $\mathrm{S}$ - salbutamol on isolated bronchial rings contracted with carbachol or histamine at a submaximal concentration (EC70). A second study evaluated the effects of $\mathrm{R}$ - and $\mathrm{S}$ - salbutamol on semi-logarithmic cumulative concentration response curves induced by carbachol or histamine. Specific software was used to calculate statistical significance and the appropriate sigmoidal curve-fitting model.

Results: Neither enantiomers of salbutamol caused a relaxant effect on the sub-maximal plateau contractile effects of carbochol; in fact, both R- and S-salbutamol induced a slight, but significant contraction $(\mathrm{P} \leq 0.05)$ compared to the controls. In contrast, R-salbutamol induced a significant relaxation of bronchi precontracted with histamine (RAO-unaffected:

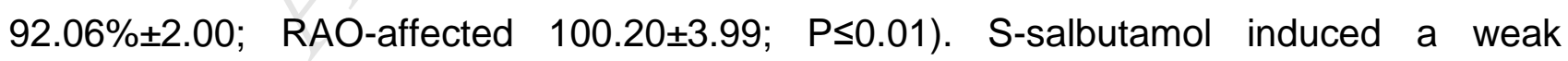
relaxation (RAO-unaffected: $15.81 \% \pm 5.65$; RAO-affected1 $2.36 \pm 5.15$ ) when compared to that induced by papaverine. The incubation with either R- or S-salbutamol shifted rightward $(\mathrm{P} \leq 0.001)$ the carbachol contraction curve in RAO-unaffected bronchi, but not in RAOaffected bronchi, compared to control tissues. R-salbutamol induced a reduction in Emax values (C: 9.07gr \pm 0.68 ; R-salb.: 6.36gr $\pm 0.21 ; P \leq 0.01$ ) in normal bronchi. On the contrary it reduced the histamine potency in RAO-affected bronchi (EC50 $7.10 \mu \mathrm{M} \pm 0.35, \mathrm{P}<0.001$ ). 
The incubation with S-salbutamol shifted leftward the histamine concentration curve in both normal bronchi (C: $7.00 \mu \mathrm{M} \pm 0.29$; S-salb.: $2.25 \mu \mathrm{M} \pm 0.19$; $\mathrm{P} \leq 0.001$ ) and bronchi from RAOaffected horses (C: $2.80 \mu \mathrm{M} \pm 0.26$; S-salb.: $1.50 \mu \mathrm{M} \pm 0.80 ; \mathrm{P} \leq 0.05)$.

Conclusion: Our studies have demonstrated that S-salbutamol elicited a modest increase in contraction of equine airway smooth muscle induced by carbachol and induced a significant hyperresponsiveness to histamine. These results confirm the ability of the Senantiomer of salbutamol to potentiate the contractile effect of certain spasmogens on airway smooth muscle. Such an adverse effect would be determined in the airways of horses with RAO and suggest that if salbutamol is to be used in the treatment of symptoms of RAO in horses, the R-enantiomer, rather than the racemic mixture should be considered.

Keywords: salbutamol, enantiomers, equine isolated bronchi, RAO. 


\section{Introduction}

There is an increasing amount of evidence demonstrating an association of inhaled $\beta_{2}$ agonists with a rise in asthma-related deaths and life-threatening experiences, as well as an ability of $\beta_{2}$-agonists to induce bronchial hyperresponsiveness when used clinically, particularly when administered as monotherapy [1]. The mechanisms contributing to the adverse effects in the airways are not known, but it has been suggested that some of these undesirable effects maybe due to the S-enantiomer as most commonly available $\beta_{2}$ agonists are produced as racemic mixtures of $\mathrm{R}$ - and $\mathrm{S}$-enantiomers in equal ratios [2]. The S-enantiomer of salbutamol has been considered to be largely inert or at best to have weak $\beta_{2}$-agonist activities. However, recent studies have documented that S-salbutamol can potentiate the effects of spasmogens in airway smooth muscle from both guinea-pigs and humans, with a number of clinical studies also reporting worsening of airways hyperresponsiveness in animals [3] and in subjects with asthma [4]. It has also been documented that the metabolic clearance of S-salbutamol occurs much less rapidly than Rsalbutamol [5], and thus the paradoxical responses may persist after the beneficial effects of (R)-salbutamol have waned [2], particularly after chronic use of the drug. S-salbutamol has also been reported to have proinflammatory effects that could negatively affect the airways [6].

Chemically, all $\beta$-agonists are racemates, or drugs composed of two non-superimposable mirror image molecules in a 50/50 ratio [7]. These molecules are classified as R- or Saccording to their molecular configuration, and as 'lev' or 'dex' based on the rotation of polarised light as it passes through the molecule.

Equine obstructive pulmonary disease, also known as heaves or recurrent airway obstruction (RAO) is a common equine pulmonary disease with certain similarities to human asthma and COPD and represents a major cause of morbidity and loss of lung performance in this species [8,9].

Whilst $\beta_{2}$-agonists are used in the treatment of RAO, little is known about the properties of the enantiomers of salbutamol in the horse. The present study has therefore evaluated effects of racemic $\beta_{2}$-agonists in isolated equine bronchi in comparison with the pure $\mathrm{R}$ and S-enantiomers. 


\section{Materials and Methods}

Equine lungs, derived from healthy horses following humane killing in an abattoir, were obtained from six RAO-unaffected horses ( 3 male and 3 female; aged $2.3 \pm 0.1$ years; weighted $\mathrm{kg} 375 \pm 54.3$ ) and four RAO-affected horses ( 2 male and 1 female; aged $2.5 \pm$ 0.2 years; weighted $\mathrm{kg} 388 \pm 46.5)$. Lungs were rapidly transported to our laboratory in a Krebs-Henseleit solution (KH) (composition, $\mathrm{mM}: \mathrm{NaCl}$ 117.5. $\mathrm{KCl} 5.60 . \mathrm{MgSO}_{4}$ 1.18. $\mathrm{CaCl}_{2}$ 2.50. $\mathrm{NaH}_{2} \mathrm{PO}_{4}$ 1.28. $\mathrm{NaHCO}_{3} 25.00$ and glucose 5.5, pregassed with $=\mathrm{O}_{2} / \mathrm{CO}_{2}$ 95:5\% v/v. pH7.4). Segmental bronchi, typically $3-5 \mathrm{~mm}$ in diameter, were derived from each set of lungs and dissected free from connective tissue and cut into rings. Epithelium intact bronchial rings were transferred into organ baths containing $\mathrm{KH}$-buffer $\left(37^{\mathrm{C}} \mathrm{C}\right.$ ), treated with indomethacin $(10 \mu \mathrm{M})$ in order to inhibit cyclo-oxygenase enzymes and so prevent prostaglandin formation and any intrinsic tissue activity. Tissues were continuously gassed with $\mathrm{O}_{2} / \mathrm{CO}_{2} 95: 5 \mathrm{v} / \mathrm{v}$. Bronchial rings were connected to an isometric force displacement transducer and were allowed to equilibrate for $90 \mathrm{~min}$ containing modified with the $\mathrm{KH}$ buffer being changed every $10 \mathrm{~min}$. During equilibration $(2 \mathrm{~h}$ ) optimal passive tension were determined by gentle stretching of tissue $(\cong 2 \mathrm{~g})$. The isometric changes in tension was measured with a transducer Fort 10 WPI (Basile Instruments. Italy).

The tissue responsiveness was assessed using acetylcholine (ACh) $100 \mu \mathrm{M}$; when the response reached a plateau, rings were washed three times and allowed to equilibrate for a further $60 \mathrm{~min}$.

\section{Study design}

Protocol 1: Relaxant effect of salbutamol enantiomers on submaximal contractions induced by carbachol or histamine.

Following equilibration of the tissues, semi-logarithmic concentration-response curves induced by carbachol (dose from $10 \mathrm{nM}$ to $100 \mu \mathrm{M}$ ) or histamine (10 $\mathrm{nM}$ to $100 \mu \mathrm{M}$ ) were constructed in order to establish the baseline contractility of tissues and the concentration 
inducing a sub-maximal contraction (70\%). The bronchial rings were washed a further three times and allowed to stabilize for about $30 \mathrm{~min}$ following the last washing.

In order to evaluate the relaxant effects of salbutamol enantiomers, in all rings contracted with carbachol and histamine at the sub maximal concentration (EC70), a concentration semi-logarithmic curve to salbutamol enantiomers or the racemic mixture was constructed at concentrations ranging from $0.1 \mathrm{nM}$ to $100 \mu \mathrm{M}$ for each compound. Each concentrationresponse curve was obtained by the cumulative addition of R-, S- or racemic salbutamol at intervals of 5-15 min to reach a stable level of relaxation before the next addition was made. In the control groups a cumulative concentration of vehicle was added in the organbaths and used as a time control. At the end of the experiments papaverine $(500 \mu \mathrm{M})$ was added to the bronchial rings to determine the maximal relaxant response achievable for each isolated bronchus. Similar experiments of protocol 1 were repeated in bronchi from RAO-affected horses.

Protocol 2: Effects of salbutamol enantiomers on smooth muscle contraction induced by carbachol or histamine.

In order to evaluate the effects of salbutamol enantiomers on carbachol and histamineinduced contraction, concentration-contraction semi-logarithmic curves to carbachol or histamine (10 nM to $100 \mu \mathrm{M}$ ) were constructed from bronchi pre-incubated with R-, S- or racemic salbutamol $(100 \mu \mathrm{M})$ for $90 \mathrm{~min}$. The control bronchi were pre-incubated with vehicle which also served as a time control.

\section{Analysis}

All experiments were carried out on bronchi isolated from the lungs of six different horses $(n=6)$. Appropriate curve-fitting to a sigmoidal model was used to calculate the effect, the maximal response, the dose inducing 50\% maximal effect and the dose inducing $70 \%$ maximal effect ( $E, E m a x, E C 50$ and EC70 respectively). The equation used was $\log$ (agonist) vs. response, Variable slope, expressed as Y=Bottom + (TopBottom $) /\left\{1+10^{\wedge}\left[(\operatorname{LogEC} 50-\mathrm{X})^{*}\right.\right.$ HillSlope $\left.]\right\}$. The relaxant responses were expressed as percentage of papaverine $(500 \mu \mathrm{M})$ induced relaxation. All values are presented as mean \pm SEM of $n$ subject in each treatment group. Statistical significance was assessed by Student's $t$ test or one- or two-way analysis of variance (ANOVA), with Dunnett's or Bonferroni post-tests respectively. The level of statistical significance was defined as $P \leq$ 
0.05. All data analyses were performed using computer software (GraphPad Prism version 5.00 for Windows, GraphPad Software, San Diego California USA).

\section{Drugs}

Acetylcholine, carbachol and histamine were dissolved in $\mathrm{KH}$ solution; papaverine was dissolved in distilled water; R-, S- and racemic salbutamol were dissolved in distilled water; indomethacin was dissolved in ethanol and the maximal amount of ethanol $(0.02 \%)$ did not influence the response of isolated bronchi. Stock solutions $(1 \mathrm{mM})$ of each of the tested substances were prepared in distilled water, diluted with $\mathrm{KH}$ solution and prepared fresh on each day of study. The substances were obtained from Sigma-Aldrich (St. Louis, USA), RS- and racemic salbutamol were obtained from Stirling Products Ltd (Sydney, Australia) .

\section{Results}

Protocol 1: Relaxant effect of salbutamol enantiomers on submaximal contractions induced by carbachol or histamine

The baseline tension of bronchial tissues did not change throughout the experiments carried out with S-Salbutamol or the racemic mixture.

In the control bronchi, papaverine completely relaxed equine bronchial rings contracted with a sumaximal concentration of carbachol (CCh: $+4.37 \mathrm{gr} \pm 0.42$; $\mathrm{P}:-4.64 \mathrm{gr} \pm 0.45$ ) or histamine (His: $+6.59 \mathrm{gr} \pm 0.98 ; \mathrm{P}:-7.93 \mathrm{gr} \pm 0.85$ ). In contrast, salbutamol enantiomers did not show direct relaxant effects on the sub-maximal plateau contractile response induced by carbachol in either RAO-affected or RAO-unaffected bronchi. On the contrary, both enantiomers of salbutamol induced a slight but significant increase $(P \leq 0.05)$ of the carbachol baseline. Furthermore, racemic salbutamol showed a similar trend to the induced enantiomers (Figure 1; Table 1).

R-salbutamol induced a significant $(P<0.05)$ relaxation of the histamine sub-maximal plateau contractile response (RAO-unaffected: Emax 92.06\% \pm 2.00 , EC50 $0.55 \mu \mathrm{M} \pm 0.06$; RAO-affected: $100.20 \% \pm 3.99$, EC50 $0.40 \mu \mathrm{M} \pm 0.04)$. S-salbutamol induced a weak relaxation (RAO-unaffected: $15.81 \% \pm 5.65$; RAO-affected: $12.36 \pm 5.15)$ when compared to that induced by papaverine on the histamine response that was significant $(P \leq 0.01)$ only at the higheest concentrations used. Moreover, the racemic compound was analogous to the 
R-salbutamol effect, but eliciting a smaller Emax, particularly in bronchi from RAO-affected horses (Figure 1; Table2).

In all bronchial rings the vehicle did not induce any relaxation of the bronchi.

\section{Protocol 2: Effects salbutamol enantiomers on smooth muscle contraction induced by} carbachol or histamine

Carbachol and histamine induced a concentration-dependent contraction of equine isolated bronchi; the incubation with $\mathrm{KH}$ did not elicit any effect on equine isolated bronchial rings (figure 2). The EC70 of carbachol and histamine are presented in Table 3. The incubation with R- or S-salbutamol shifted to the right the carbachol contraction curve compared to the controls $(P \leq 0.001)$ at concentrations ranging from $0.3 \mu \mathrm{M}$ to $100 \mu \mathrm{M}$; both $\mathrm{R}$ - and $\mathrm{S}$ salbutamol showed a significant reduction in Emax (R-salb.: $P \leq 0.001$; S-salb.: $P \leq 0.05$ ) with a significant increase in the EC50 (R-salb.: $P \leq 0.001$; S-salb.: $P \leq 0.05$ ); the trend of the carbachol induced contraction curves after the incubation with racemic mixture of salbutamol was analogous to effects elicited by the individual enantiomers (figure 2, table 3).

R-salbutamol caused a significant shift to the right of the cumulative concentrationcontraction curve of histamine, with a significant reduction in Emax values (C: $9.07 \mathrm{gr} \pm 0.68$; R-salb: $6.36 \mathrm{gr} \pm 0.21 ; \mathrm{P} \leq 0.01$ ) but without any significantly change on EC50 values (C: $7.00 \mu \mathrm{M} \pm 0.29$; R-salb: $7.25 \mu \mathrm{M} \pm 1.06 ; \mathrm{P}<0.05$ ). In contrast the incubation with $\mathrm{S}$-salbutamol shifted leftward the histamine concentration curve when compared to the left when compared with controls, with a significant reduction of EC50 values (C: $7.00 \mu \mathrm{M} \pm 0.29$; Ssalb: $2.25 \mu \mathrm{M} \pm 0.19 ; \mathrm{P} \leq 0.001$ ) but without any significant change on Emax values (C: 9.07gr \pm 0.68 ; S-salb: 8.12gr $\pm 0.51 ; P<0.05)$. The trend of the histamine induced contraction curves after incubation with the racemic mixture of salbutamol was similar to the effects induced by the S-isomer, but with Emax values significantly different when compared to control tissues (figure 2, table 3).

The contractile response to carbachol did not change in bronchi from RAO-affected horses, whereas the contractile potency of histamine was significantly enhanced in bronchi from RAO-affected horses (EC50 2.8 $\mu \mathrm{M} \pm 0.26$ ), compared to tissue obtained from RAOunaffected horses. In RAO-affected bronchi, R- and S- enantiomers of salbutamol and the racemic mixture did not alter the concentration response curve to carbachol compared to 
control tissues $(P>0.05)$. On the contrary, the contractile response to histamine was shifted leftwards by $\mathrm{S}$-salbutamol $(\mathrm{EC50} 1.50 \mu \mathrm{M} \pm 0.80, \mathrm{P}<0.05)$ whereas it was shifted rightward by R-salbutamol (EC50 7.10 $\mu \mathrm{M} \pm 0.35, \mathrm{P}<0.001$ ). In bronchi from RAO-affected horses the racemate did not change the contraction induct by histamine $(P>0.05)$ (figure 2 , table 3 ).

\section{Discussion}

Inhaled $\beta_{2}$-agonists remain the first line treatment of acute symptoms of airway obstructive diseases in horses. Most commonly available $\beta_{2}$-agonist preparations are racemic, i.e. they are composed of an equimolar mixture of $\mathrm{R}$ - and $\mathrm{S}$ - stereoisomers. Traditionally the $\mathrm{S}$ enantiomers were considered inert or at best weak $\beta_{2}$-agonists [10], but it is now recognized that the S-enantiomer can have adverse effect in the airways [2]. Thus, it has been documented in in vitro and in vivo experimental studies that S-salbutamol can be proinflammatory and have pro-constrictor effects in airways. These results are in agreement with clinical studies that have demonstrated that S-salbutamol can induce airway hyperresponsiveness in patients with asthma. It has been suggested that these paradoxical responses may be reduced by removing the dose of $S$ - enantiomers [5, 11]. Besides, Rsalbutamol is now commonly available for the treatment of obstructive lung disease and further $\mathrm{R}$-isomers preparations of $\beta_{2}$-agonist are under development in man (3)

Like human obstructive bronchial diseases, equine obstructive pulmonary disease, also known as heaves or recurrent airway obstruction (RAO), is a common equine chronic pulmonary disease, in which the prominent symptom is airway obstruction which is treated with $\beta_{2}$ agonists $[8,9]$. Our present study shows that S-salbutamol has adverse proconstrictory effects in equine bronchi, particularly in bronchi from RAO-affected horses.

Previous studies carried out with isolated equine trachea have demonstrated that $\beta_{2}-$ agonists facilitate acetylcholine release from prejunctional cholinergic nerves by the stimulation of prejunctional $\beta_{2}$-receptors localized on parasympathetic nerve endings [11, 12]. Moreover, the S-enantiomers of two $\beta_{2}$-agonists (salbutamol and formoterol) elicited a significant increase in acetylcholine release in the presence of $\mathrm{M}_{2}$ receptor blockade, and suggested a potential deleterious effect of (S)- $\beta_{2}$ agonists in the lungs of horses with RAO [13]. To our knowledge, this is the first paper to focus on the effects of the R- and S- 
enantiomers of salbutamol on isolated bronchi obtained from Either normal or RAO affected horses.

Our results are consistent with an effect of acetylcholine release, as demonstrated by Zhang and co-workers [12-14]. Furthermore, it has also been postulated that S-salbutamol has a possible agonistic effect on $M_{3}$ muscarinic receptors postjunctionally, via a mechanism that involves an increase of intracellular calcium in airway smooth muscle [13, 14]. According with this hypothesis, and considering that the affinity of $S$-isomer for $\beta-$ adrenoceptors is $>100$ fold lower than R-isomer, Mitra and coworkers suggested that $S$ salbutamol could work as an agonist for muscarinic receptors cross-reacting with $M_{3}$ receptors, acting also as a calcium agonist [14]. Moreover, several studies have shown that an exaggerated cholinergic stimulation of airway smooth muscle causes a reduction in the ability of $\beta_{2}$-agonists to relax airway smooth muscle $[16,17]$. These results could suggest that both enantiomers of salbutamol could have deleterious effects in equine airways, particularly in RAO-affected horses. However, our results have demonstrated that Rsalbutamol functionally antagonized the carbachol concentration contraction curve in normal bronchi, but not in bronchi obtained from horses with RAO. Furthermore, Rsalbutamol postjunctionally inhibited the smooth muscle tone induced by both histamine and carbachol in a significant manner in both normal and RAO bronchi. In addition, on equine carbachol precontracted tracheal strips, we have provided evidence that $\mathrm{S}$ salbutamol had a modest, but significant, bronchoconstrictor effect [13, 18]. These data may support the deleterious role of S-salbutamol, particularly in RAO-affected horses, in which the $\beta_{2}$-adrenergic receptor- $G_{s}$-protein-adenylate cyclase system is significantly impaired in membranes of peripheral lung and bronchi, when compared with the segments from control animals [19].

In contrast with the observations on carbachol precontracted equine bronchi, the results of our study demonstrated that R-salbutamol relaxed equine isolated airways contracted with histamine. Moreover, the cumulative concentration-contraction curve to histamine was significantly shifted rightward with a significant increase of its EC50 when both normal and RAO equine bronchi were incubated with R-salbutamol, compared to controls tissues.

Our findinge are in line with results obtained in bovine tracheal smooth muscle, in which the contraction induced by muscarinic agonists was relatively resistant to relaxation by $\beta_{2}-$ agonists, compared to the contraction induced by histamine [17]. In fact, this spasmogen 
induced a less marked calcium mobilization and influx when compared to that induced by methacholine [16], which is less susceptible to elevations of c-AMP [20].

As expected, we observed a less marked relaxant effect of S-salbutamol, that was significant only at the highest concentration and certainly less effective than papaverine. In addition, we found a significant leftward shift of the histamine cumulative concentration contraction curve, with an increase of histamine potency, when normal airways or bronchi from RAO-affected horses were incubated with S-salbutamol, compared to control tissues. In line with these results, it has been documented that detrimental effects of the racemic mixture of $\beta_{2}$-agonists are strictly related to the S-isomers [2, 6, 21, 22]. Although, Ssalbutamol induced a weak relaxation of equine isolated bronchi pre-contracted by histamine, it induced an increase in airway smooth muscle responsiveness to the cumulative dose response to this spasmogen in both normal and RAO bronchi. In agreement with these findings, racemic salbutamol induced an exaggerated conctractile response to histamine in airway tissues obtained from sensitized from guinea pigs [21]. It has been speculated that the pro-inflammatory and pro-constrictory activity of S-isomer, are mediated by the activation of transcriptional nuclear factor $\mathrm{kB}$ (NF-kB) as has been demonstrated in human isolated airways[23]. . These findings were also confirmed in other animal models of bronchial hyperresponsiveness. Thus it has been reported that $\mathrm{S}$ salbutamol potentiates the pro-constrictory activity of histamine and IL-4 in sensitized guinea pigs [24], by stimulating the production of IL-2 and IL-13 in T-cells [25]. Over all, these cytokines shift the coupling of the $\beta_{2}$-adrenergic receptors to pro-constrictory $G$ proteins such as $G_{i d-1}$ protein [19]. Considering all these data, it is possible to hypothesize an analogous pro-inflammatory and pro-constrictory activity of S-salbutamol also in equine airways after only $90 \mathrm{~min}$. of incubation,enhancing the potency of histamine, as has been demosntrated in human bronchi after passive sensitization [26].

In conclusion, our studies demonstrated that S-salbutamol elicited a weak contraction of equine airway smooth muscle, but induced a significant hyperresponsiveness to histamine that could be detrimental particularly in RAO-affected horses [27-30]. Our results suggest that it may be prudent to administrate the R-isomer alone in RAO horses to avoid detrimental effect of S-isomer.

\section{References}


1. Cazzola M, Matera MG. Safety of long-acting $\beta_{2}$-agonists in the treatment of asthma. Ther Adv Respir Dis 2007;1:35-46

2. Page CP, Morley J. Contrasting properties of albuterol stereoisomers. J Allergy Clin Immunol 1999;104:S31-41

3. Gupta MK and Singh M. Evidence based review on levosalbutamol. Indian J Pediatr. 2007;74:161-67

4. Perrin FM, Blum PS, Morley J, Grosclaude M, Chambe MT. Differential responses of asthmatic airways to enantiomers of albuterol. Implications for clinical treatment of asthma. Clin Rev Allergy Immunol 1996;14:139-47

5. Spitzer WO, Suissa S, Ernst P, Horwitz RI, Habbick B, Cockcroft D, et al. The use of $\beta$-agonists and the risk of death and near death from asthma. $N$ Engl $J$ Med $1992 ; 326: 501-6$

6. Agrawal DK, Ariyarathna K, Kelbe PW. (S)-Albuterol activates pro-constrictory and pro-inflammatory pathways in human bronchial smooth muscle cells. $J$ Allergy Clin Immunol 2004;113:503-10

7. Handley DA, Morley J. The pursuit of precision pharmaceuticals: divergent effects of $\beta_{2}$ agonist isomers. Expert Opin Investig Drugs 1998;7:1601-16

8. Robinson NE, Derksen FJ, Olszewski MA, Buechner-Maxwell VA. The pathogenesis of chronic obstructive pulmonary disease of horses. Br Vet J 1996;152:283-306

9. Matera MG, Amorena M, Lucisano A. Innervation of equine airways. Pulm Pharmacol Ther 2002; 15:503-11

10. Penn RB, Frielle T, McCullough JR, Aberg G, Benovic JL. Comparison of R-, $S$-, and $R S$-albuterol interaction with human $\beta_{1}$ - and $\beta_{2}$-adrenergic receptors. Clin Rev Allergy Immunol 1996;14:37-45

11. Cazzola M, Matera MG, Donner CF. Inhaled $\beta_{2}$-adrenoceptor agonists: cardiovascular safety in patients with obstructive lung disease. Drugs 2005;65:1595-610

12. Zhang $X Y$, Olszewski MA, Robinson NE. $\beta_{2}$-adrenoceptor activation augments acetylcholine release from tracheal parasympathetic nerves. Am $J$ Physiol 1995;268:L950-6

13. Zhang $X Y$, Zhu FX, Robinson NE. Excitatory prejunctional $\beta_{2}$-adrenoceptor distribution within equine airway cholinergic nerves. Respir Physiol 1996;106:81-90 
14. Zhang XY, Zhu FX, Olszewski MA, Robinson NE. Effects of enantiomers of $\beta_{2^{-}}$ agonists on ACh release and smooth muscle contraction in the trachea. Am J Physiol 1998;274:L32-8

15. Mitra S, Ugur M, Ugur O, Goodman HM, McCullough JR, Yamaguchi H. (S)-Albuterol increases intracellular free calcium by muscarinic receptor activation and a phospholipase C-dependent mechanism in airway smooth muscle. Mol Pharmacol 1998;53:347-54

16. Van Amsterdam RG, Meurs H, Brouwer F, Postema JB, Timmermans A, Zaagsma J. Role of phosphoinositide metabolism in functional antagonism of airway smooth muscle contraction by $\beta$-adrenoceptor agonists. Eur J Pharmacol 1989;172:175-183

17. Boterman M, Smits SRJG, Meurs H, Zaagsma J. Protein kinase C potentiates homologous desensitization of the $\beta_{2}$-adrenoceptor in bovine tracheal smooth muscle. Eur J Pharmacol 2006;529:151-156

18. Johansson F, Rydberg I, Aberg G, Andersson RG. Effects of albuterol enantiomers on in vitro bronchial reactivity. Clin Rev Allergy Immunol 1996;14:57-64

19. Abraham G, Kottke C, Dhein S, Ungemach FR. Agonist-independent alteration in $\beta$ adrenoceptor-G-protein-adenylate cyclase system in an equine model of recurrent airway obstruction. Pulm Pharmacol Ther 2006;19:218-29

20. Hoiting BH, Meurs H, Schuiling M, Kuipers R, Elzinga CR, Zaagsma J. Modulation of agonist-induced phosphoinositide metabolism, $\mathrm{Ca}^{2+}$ signalling and contraction of airway smooth muscle by cyclic AMP-dependent mechanisms. $\mathrm{Br} J$ Pharmacol 1996;117:419-26

21. Hoshiko K, Morley J. Exacerbation of airway hyperreactivity by (+/-)salbutamol in sensitized guinea pig. Jpn J Pharmacol 1993;63:159-63

22. Mazzoni L, Naef R, Chapman ID, Morley J. Hyperresponsiveness of the airways following exposure of guinea-pigs to racemic mixtures and distomers of $\beta_{2}$-selective sympathomimetics. Pulm Pharmacol 1994;7:367-76

23. Abraha D, Cho SH, Agrawal DK, Park JM, Oh CK. (S,S)-formoterol increases the production of IL-4 in mast cells and the airways of a murine asthma model. Int Arch Allergy Immunol 2004;133:380-8 
24. Cho SH, Hartleroad JY, Oh CK. (S)-albuterol increases the production of histamine and IL-4 in mast cells. Int Arch Allergy Immunol 2001;124:478-84

25. Baramki D, Koester J, Anderson AJ, Borish L. Modulation of T-cell function by (R)and (S)-isomers of albuterol: anti-inflammatory influences of $(\mathrm{R})$-isomers are negated in the presence of the (S)-isomer. J Allergy Clin Immunol 2002;109:449-54

26. Watson N, Bodtke K, Coleman RA, Dent G, Morton BE, Rühlmann E, et al. Role of IgE in hyperresponsiveness induced by passive sensitization of human airways. $A m \mathrm{~J}$ Respir Crit Care Med 1997;155:839-44

27. Scott JS, Broadstone RV, Derksen FJ, Robinson NE. $\beta$-adrenergic blockade in ponies with recurrent obstructive pulmonary disease. J Appl Physiol 1988;64:2324-8

28. Hare JE, Viel L. Pulmonary eosinophilia associated with increased airway responsiveness in young racing horses. J Vet Intern Med 1998;12:163-70

29. Wong DM, Buechner-Maxwell VA, Manning TO, Ward DL. Comparison of results for intradermal testing between clinically normal horses and horses affected with recurrent airway obstruction. Am J Vet Res 2005;66:1348-55

30. Deaton CM, Deaton L, Jose-Cunilleras E, Vincent TL, Baird AW, Dacre K, et al. Early onset airway obstruction in response to organic dust in the horse. J Appl Physiol 2007;102:1071-7 
Table 1. Relaxant effects of $R, S$ and racemic mixture of salbutamol on equine isolated bronchi (normal and RAO-affected horses) contracted with carbachol (negative values mean a contraction). All values are mean \pm SEM of six (normal bronchi) and four (bronchi from RAO horses) samples. * $\mathrm{P} \leq 0.05$ vs baseline; ${ }^{\circ} \mathrm{P} \leq 0.05$ vs normal bronchi; nd: not detectable.

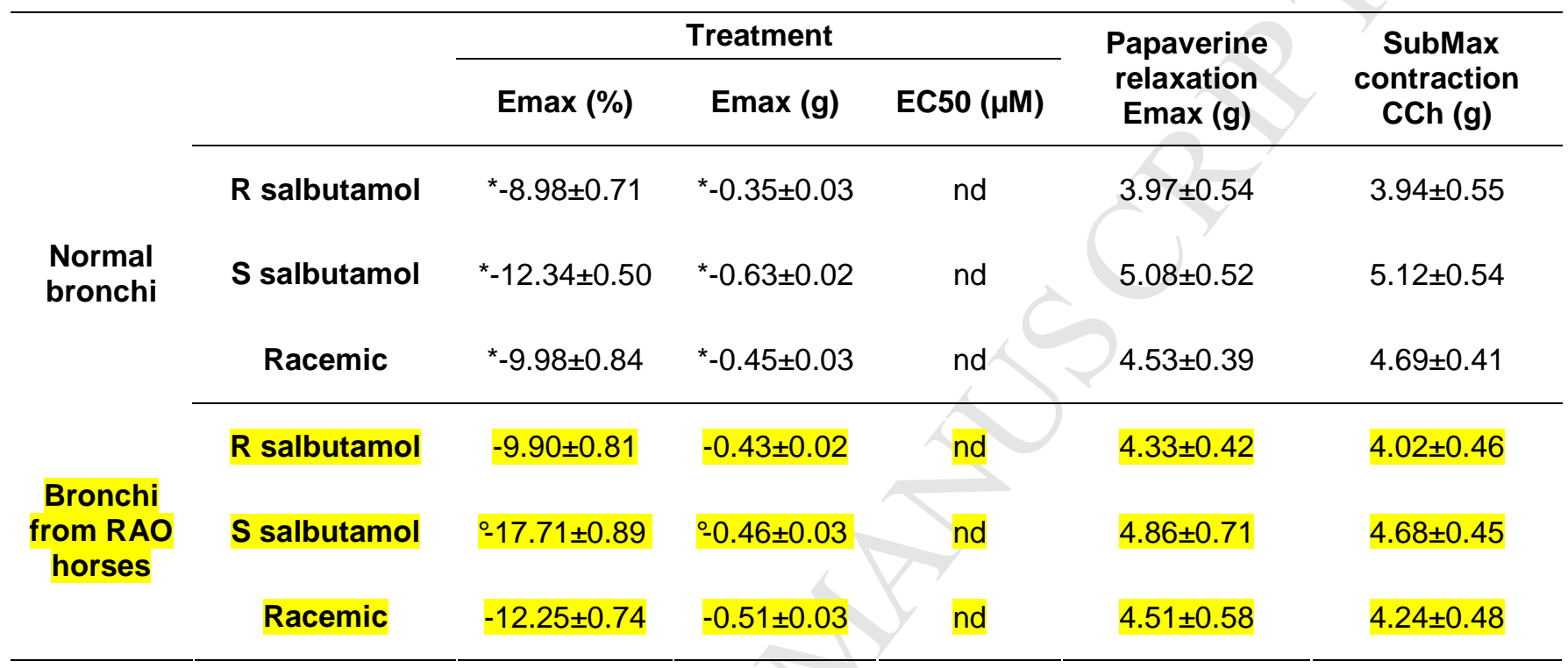


Table 2 - Relaxant effects of $\mathbf{R}$ - and S- salbutamol on equine isolated bronchi (normal and RAO-affected horses) contracted with histamine. All values are mean \pm SEM of six (normal bronchi) and four (bronchi from RAO horses) samples. ${ }^{*} \mathrm{P} \leq 0.05$, ${ }^{* *} \mathrm{P}$ $\leq 0.01$ and ${ }^{* *} \mathrm{P} \leq 0.001$ vs baseline; ${ }^{\circ} \mathrm{P} \leq 0.05$ and ${ }^{\infty} \mathrm{P} \leq 0.01$ vs normal bronchi; nd: not detectable.

\begin{tabular}{|c|c|c|c|c|c|c|}
\hline & & \multicolumn{3}{|c|}{ Treatment } & \multirow{2}{*}{$\begin{array}{l}\text { Papaverine } \\
\text { relaxation } \\
\text { Emax }(g)\end{array}$} & \multirow{2}{*}{$\begin{array}{l}\text { SubMax } \\
\text { contraction } \\
\text { His }(g)\end{array}$} \\
\hline & & $\operatorname{Emax}(\%)$ & $\operatorname{Emax}(\mathrm{g})$ & EC50 $(\mu \mathrm{M})$ & & \\
\hline \multirow{3}{*}{$\begin{array}{l}\text { Normal } \\
\text { bronchi }\end{array}$} & R salbutamol & ${ }^{* * *} 92.06 \pm 2.00$ & ${ }^{* * *} 8.55 \pm 0.18$ & ${ }^{* * \star} 0.55 \pm 0.06$ & $9.29 \pm 0.31$ & $7.56 \pm 1.00$ \\
\hline & S salbutamol & ${ }^{* *} 15.81 \pm 5.65$ & ${ }^{* *} 1.16 \pm 0.41$ & nd & $7.40 \pm 0.97$ & $5.07 \pm 1.06$ \\
\hline & Racemic & $* * \star 81.12 \pm 3.67$ & $* * * 7.13 \pm 0.74$ & ${ }^{* \star *} 0.30 \pm 0.04$ & $8.79 \pm 0.92$ & $6.68 \pm 0.83$ \\
\hline \multirow{3}{*}{$\begin{array}{c}\text { Bronchi } \\
\text { from RAO } \\
\text { horses }\end{array}$} & R salbutamol & $900.20 \pm 3.99$ & $9.43 \pm 0.29$ & ${ }^{\infty} 0.40 \pm 0.04$ & $9.42 \pm 0.29$ & $8.98 \pm 0.86$ \\
\hline & S salbutamol & $12.36 \pm 5.15$ & $1.03 \pm 0.33$ & nd & $8.30 \pm 0.85$ & $8.02 \pm 1.12$ \\
\hline & Racemic & $64.08 \pm 3.55$ & $5.54 \pm 0.56$ & ${ }^{\infty} 0.20 \pm 0.03$ & $8.65 \pm 0.98$ & $8.50 \pm 0.98$ \\
\hline
\end{tabular}


Table 3 - Effect of $\mathbf{R}, \mathbf{S}$ and racemic mixture of salbutamol on equine isolated bronchi concentration-dependent curve to carbachol ( $\mathrm{CCh}$ ) and histamine (His). All values are mean \pm SEM of six samples. ${ }^{*} \mathrm{P} \leq 0.05,{ }^{* *} \mathrm{P} \leq 0.01$, ${ }^{* *} \mathrm{P} \leq 0.001$ vs controls; \# $\mathrm{P} \leq 0.001$ vs normal bronchi.

\begin{tabular}{|c|c|c|c|c|c|c|c|}
\hline & & \multicolumn{3}{|c|}{ CCDR CCh } & \multicolumn{3}{|c|}{ CCDR His } \\
\hline & & $\operatorname{Emax}(\mathbf{g})$ & $\mathrm{EC50}(\mu \mathrm{M})$ & $\mathrm{EC} 70(\mu \mathrm{M})$ & $\operatorname{Emax}(g)$ & $\mathrm{EC50}(\mu \mathrm{M})$ & EC70 $(\mu \mathrm{M})$ \\
\hline \multirow{4}{*}{$\begin{array}{l}\text { Normal } \\
\text { bronchi }\end{array}$} & Control & $6.97 \pm 0.15$ & $0.80 \pm 0.03$ & $1.63 \pm 0.05$ & $9.07 \pm 0.68$ & $7.00 \pm 0.29$ & $13.8 \pm 0.97$ \\
\hline & R salb. incub. & $\S 5.32 \pm 0.31$ & $\S 2.50 \pm 0.24$ & & ${ }^{* *} 6.36 \pm 0.21$ & $7.25 \pm 1.06$ & \\
\hline & S salb. incub. & ${ }^{*} 5.67 \pm 0.44$ & *2.35 20.69 & & $8.12 \pm 0.51$ & $* \star 2.25 \pm 0.19$ & \\
\hline & $\begin{array}{r}\text { Racemic } \\
\text { incubation }\end{array}$ & ${ }^{* *} 5.42 \pm 0.39$ & ${ }^{* *} 2.44 \pm 0.52$ & & $* 7.31 \pm 0.40$ & $* * * 2.00 \pm 0.25$ & \\
\hline \multirow{4}{*}{$\begin{array}{c}\text { Bronchi } \\
\text { from RAO } \\
\text { horses }\end{array}$} & Control & $6.96 \pm 0.18$ & $1.00 \pm 0.16$ & $1.55 \pm 0.09$ & $8.34 \pm 0.28$ & $\# 2.80 \pm 0.26$ & $\# 5.50 \pm 0.45$ \\
\hline & R salb. incub. & $7.07 \pm 0.26$ & $1.30 \pm 0.12$ & & $8.37 \pm 0.27$ & $* * * 7.10 \pm 0.35$ & \\
\hline & S salb. incub. & $6.84 \pm 0.21$ & $0.90 \pm 0.08$ & & $7.91 \pm 0.34$ & ${ }^{*} 1.50 \pm 0.80$ & \\
\hline & $\begin{array}{c}\text { Racemic } \\
\text { incubation }\end{array}$ & $6.89 \pm 0.31$ & $1.20 \pm 0.11$ & & $7.78 \pm 0.30$ & $2.50 \pm 0.34$ & \\
\hline
\end{tabular}


Figure 1 - Relaxant effects of $R, S$ and racemic mixture of salbutamol on isolated bronchi from RAO-unaffected (A) and RAO-affected (B) horses, pre-contracted with submaximal dose of carbachol $(\mathrm{CCH})$ or histamine (His). All values are mean $\pm \mathrm{SEM}$ of six $(A)$ and four $(B)$ samples. * $P \leq 0.05,{ }^{\#} \mathrm{P} \leq 0.01,{ }^{\S} \mathrm{P} \leq 0.001$, vs $\mathrm{CCh}$ or His baseline plateau; @ P $\leq 0.05$ vs bronchi from normal horses.

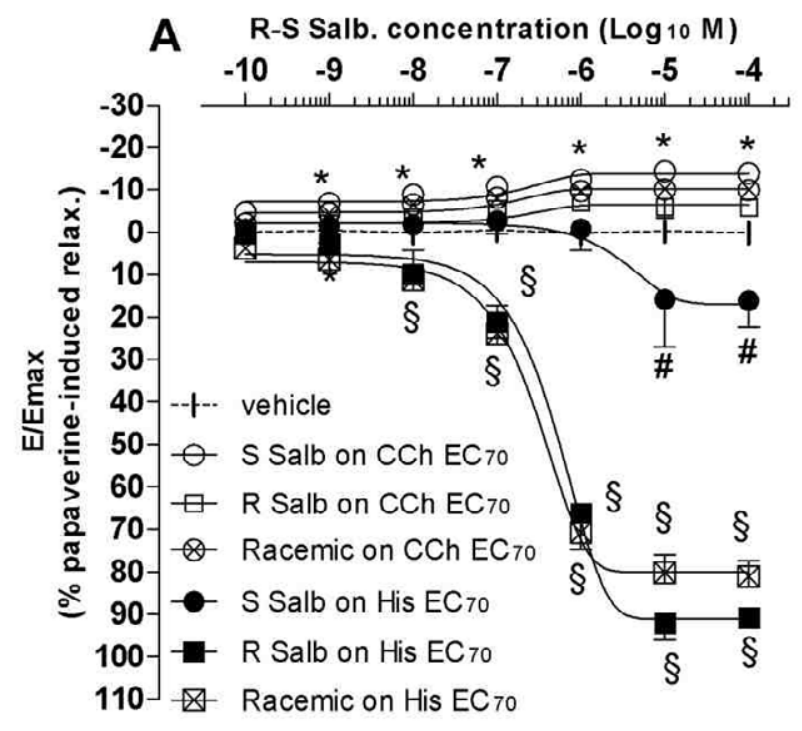

Bronchi from normal horses
B R-S Salb. concentration $(\log 10 \mathrm{M})$

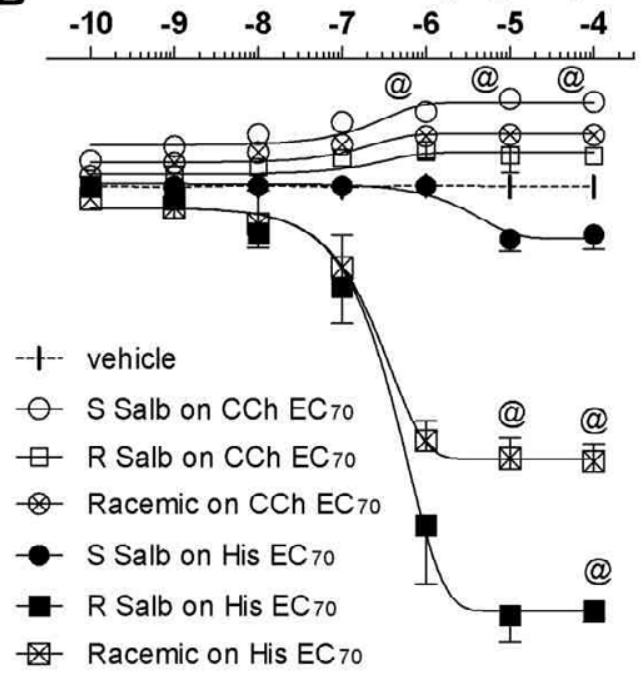

Bronchi from RAO-affected horses 
Figure 2 - Effects of $R, S$ and racemic mixture of salbutamol on the dose response curve to carbachol (CCh, A and B) and histamine (His, C and D) in bronchi from RAO-unaffected ( $A$ and $C$ ) and RAO-affected ( $B$ and $D$ ) horses. All values are mean \pm SEM of at the six ( $A$ and $C$ ) and four ( $B$ and $D)$ samples. ${ }^{*} P \leq 0.05,{ }^{\#} P \leq 0.01,{ }^{\S} P \leq 0.001$ vs control.

A Normal bronchi and CCh

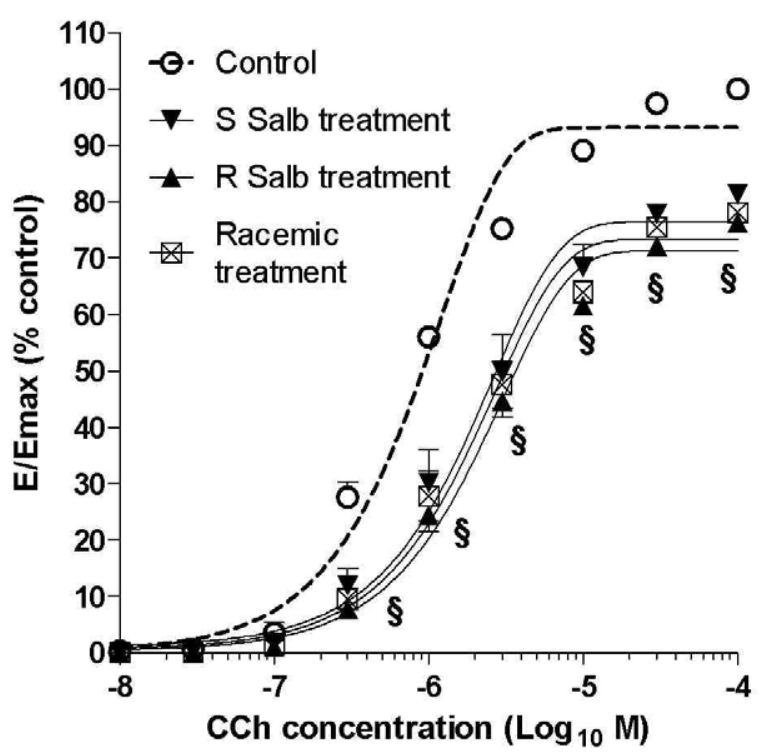

C Normal bronchi and His

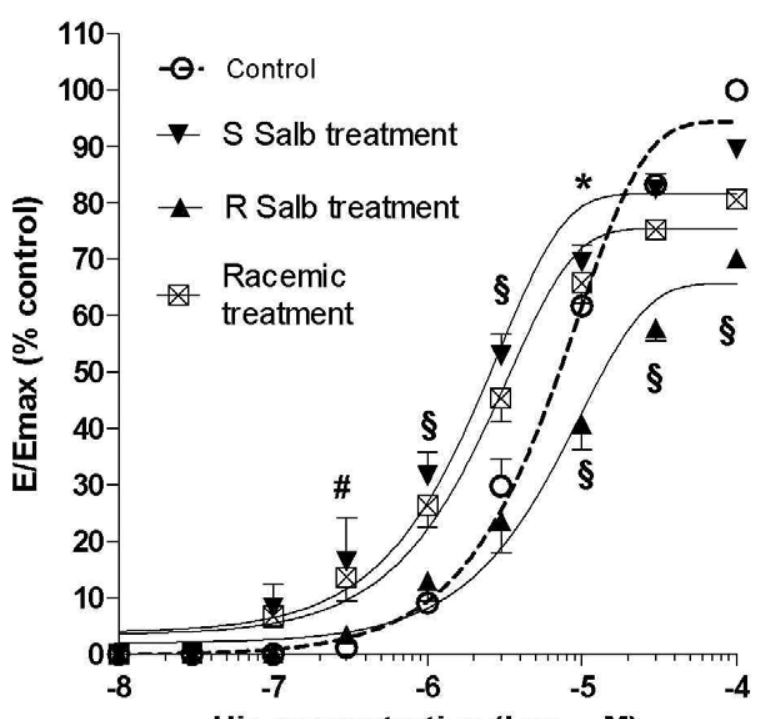

His concentration $\left(\log _{10} M\right)$

\section{B RAO bronchi and CCh}

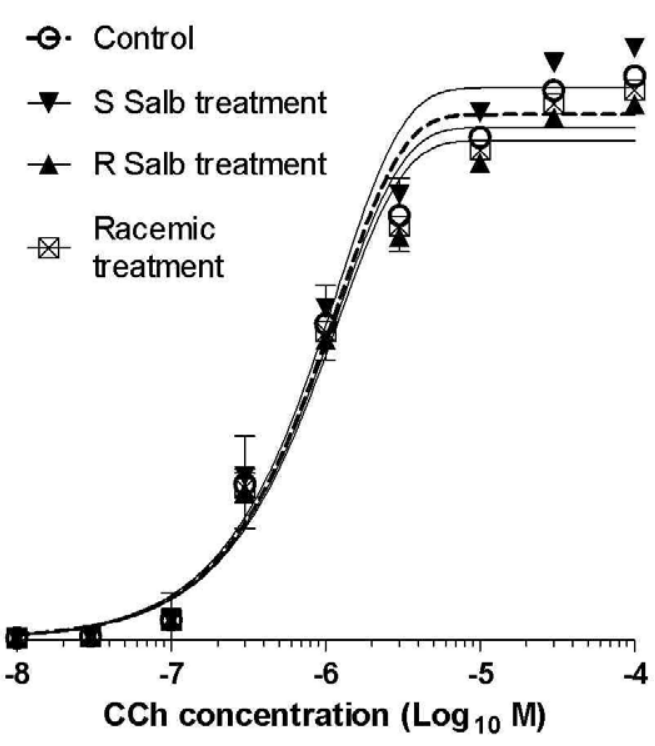

D RAO bronchi and His

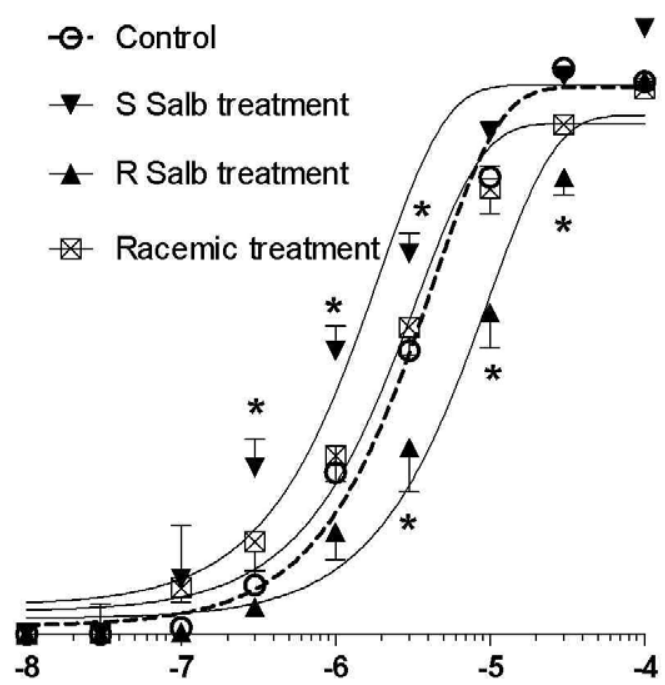

His concentration $\left(\log _{10} M\right)$ 